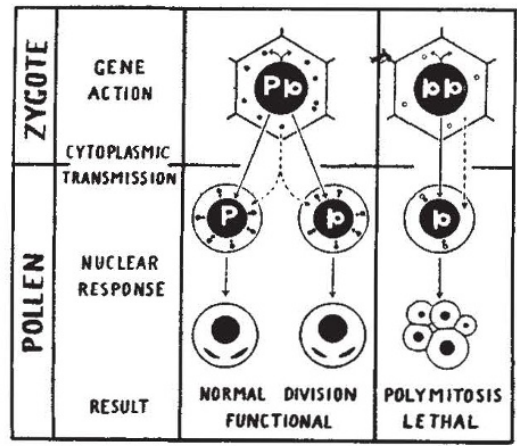

Fig. 2. POLYMitosis of THE NUCLEI IN MAIEE POLLEN GRAINS DEPENDS ON THE ACTION OF A RECESSIVE GENE IN THE SPOROPHYTE. THE NORMAI, OR POLYMITOTIC BEHAVIOUR OF THE POLLEN GRAIN'S NUCLEUS DEPENDS NOT ON THE GENE IT CARRIES, BUT ON THE CYTOPLASM THE POLLEN GRAIN INHERITED FROM ITS PARENT ZYGOTE, WHERE THE CYTOPKASM'S CONSTTTUTION WAS DETERMINTD BY THE ACTION OF THE DIPLOID NUCLEDS WITH WHICH IT WAS THEN ASSOCIATED

is lost (Fig. 1). Furthermore, the cytoplasm can, in its regulation of nuclear processes, reflect the action of a gene no longer contained in the nucleus. This we can see in Beadle's ${ }^{17}$ polymitotic maize, where plants homozygous for the gene produce pollen grains all the nuclei of which undergo premature supernumerary divisions. The chromosomes do not show corresponding divisions, so that the nuclei come to contain reduced numbers of chromosomes, some, in fact, having only one. The result is a group of pseudo pollen grains which all die. Plants heterozygous for the gene must produce two genetically different kinds of pollen, one of which will be like the lethal polymitotic pollen borme on the homozygous plants. But none of this pollen shows polymitotic behaviour. Thus polymitosis is like incompatibility in hetero. styled plants ${ }^{18}$. The nuclei of the pollen grains do not determine their own fate. Their behaviour, normal or polymitotic, is determined by the cytoplasm transmitted from the parent zygote, where, however, its constitution was determined by the diploid nucleus with which it was then associated (Fig. 2). This principle even applies to the process of elimination, for the loss of one or two $X$ 's, to give females or males, depends in Sciara on the genic constitution of the mother, from whom the cytoplasm must have been derived even though the determining gene may not have been passed on to the individual showing the elimination.

Changes of manifestation, which have no direct effect on genic constitution, and so can never of themselves cause differentiation, thus show us how the cytoplasm of one cell can be differentiated so that the fates of the daughter cells will depend, not on which daughter nucleus each obtains (for these will be alike), but on which part of the cytoplasm each inherits. By the aid of these changes we can see how the continuation and adjustment of the processes of nuclear division depend on the cytoplasm, and hence how endopolyploidy can be a response to the condition of the cytoplasm. We can even see how elimination is but another example of cytoplasmic control. Finally, we can see how the cytoplasm, in determining these changes of the nucleus, is itself reflecting the past action of that same nucleus or of some other nucleus with which it has been earlier associated.

All these nuclear changes can be interpreted as responses to an accomplished differentiation of the cytoplasm, and many of them, indeed, demand such an interpretation. The nuclear change is but a consequence of the earlier action of the unchanged nucleus. Differentiation is neither generally nor necessarily dependent on the physical elimination or unequal multiplication of the genes and chromosomes to produce what would be seen in a complete individual as a genetic unbalance; it depends on the physiological reduction or enhancement of gene action by the constitution of a cytoplasm itself reflecting the earlier action of these same genes. The nuclear changes we see are special effects rather than general causes of differentiation. They are special examples of the general process to which all differentiation must be referred.

As an organ the nucleus, like other organs, is part of the phenotype and its behaviour is under the control of its own genes acting in their customary fashion through the cytoplasm. It is true that the phenotypic changes of the nucleus may have a special significance in that some of them might mean changes of the genotype. But this should not blind us to the fact that, even though these secondary changes of genotype may have an adaptive significance in some special cases like Sciara, they are nevertheless still secondary. They still depend on a previous change of the nucleus acting as phenotype to the genotype it carried in its earlier and unchanged form. Only if we are careful to distinguish between these two aspects of the nucleus, the recently understood phenotypic as well as the long appreciated genotypic, can we hope to assess the true significance of nuclear change in differentiation.

1 White, M. J. D., “Animal Cytology and Evolution” (Univ. Press, Cambridge, 1945).

' White, M. J. D., J. Morph., 79, 323 (1946).

'White, M. J. D., J. Morph., 80, 1 (1947).

4 Janaki-Ammal, E. K., Nature, 146, 839 (1940).

'Goldschmidt, R. B., and Lin, T. P., Science, 105, 619 (1947).

- Scott, F. M., Bot. Gaz., 99, 69 (1937).

${ }^{7}$ Lorz, A. P., Bot. Rev., 13, 597 (1947).

Huskins, C. L., Nature, 161, 80 (1948).

- Berger, C. A., Pub. Carnegie Inst., Washington, 496 (1938).

${ }^{10}$ Sturtevant, A. H., and Dobzhansky, Th., Genetics, 21, 473 (1936).

11 Duncan, R. E., Amer. J. Bot., 32, 506 (1945).

"2 Darlington, C. D., 38th Annual Report John Innes Hort. Inst. 18 (1948).

${ }^{13}$ Darlington, C. D., and Mather, K., "The Elements of Genetics", Allen and Unwin, London (in the press).

14 Mather, K., Symposia Soc. Exp. Biol., 2 (in the press).

${ }^{18}$ Darlington, C. D., Nature, 140, 932 (1937).

16 Barber, H. N., J. Genet., 42, 223 (1941).

17 Beadle, G. W., Cornell Agr. Exp. Sta. Memoir, 135, 1 (1931).

${ }^{18}$ Mather, K., Nature, 153. 392 (1944).

\section{BIOLOGICAL ASPECTS OF WATER POLLUTION}

$A$

$T$ a meeting of the Association of Applied Biologists on March 22, five papers were contributed to a symposium on "Biological Aspects of Water Pollution".

Dr. B. A. Southgate, who introduced the subject, said that it includes the treatment of sewage and industrial wastes, the effect of effluents on natural waters to which they might be discharged, and the treatment of polluted water to render it fit for drinking or for other use.

The constituents of domestic sewage are mainly derived from fæces, urine, paper, soap, and vegetable and animal matter. In towns, these are usually augmented by the constituents of gas works liquor, 
which contains thiocyanate, phenols, ammonia and sulphide, and of such trade wastes as are associated with industries peculiar to the town. Effluents from manufacturing processes may contain a variety of substances in solution, such as metals or complex cyanides from the metal and electro-plating industries, or plant extracts from such operations as the retting of flax or the washing of vegetables before canning or drying. Colloidal and suspended material is derived from a number of sources, including soil and plant debris.

It is important for several reasons that such wastes should be adequately treated before discharge to surface waters, which are the chief source of domestic water supplies. A high standard of quality is frequently necessary, too, for an industrial water supply, and cases are known in which an industry has had to be moved to a fresh location because the river from which its supply was drawn had become polluted. The purity of rivers is important also to agriculture and to inland fisheries.

In the biological treatment of sewage, purification is effected by interaction of the sewage with the biological film of a percolating filter or with flocs of activated sludge. In both types of treatment bacteria, fungi and protozoa play an essential part, and in the percolating filter the scouring action of worms and fly larvæ is also necessary. Certain types of industrial waste are amenable to separate biological treatment, under anaerobic or aerobic conditions, and some can be so treated that they can be re-used in industrial processes. Inorganic substances such as chromates and cyanides, if present in industrial wastes in appreciable amounts, often have to be removed by chemical means before the effluents are discharged to streams or to sewers.

Dr. L. A. Allen, who dealt with some microbiological problems of the treatment of sewage and trade wastes, said that microscopic examination of the biological film from a percolating filter, or of an activated sludge floc, reveals a mass of bacteria and fungal hyphæ, embedded in gelatinous or mucoid material, together with smaller numbers of protozoa. This material presents to the sewage with which it comes into contact a large and active biological surface which adsorbs a large part of the colloidal and dissolved substances. Microbial metabolism then results partly in oxidation of the adsorbed material and partly in its conversion to fresh cell substance, leading to an increase in the quantity of film or sludge.

Even under most favourable conditions, the effluent discharged to a river from a sewage treatment plant may contain several hundred coliform bacteria per ml. It has been observed, however, that in the course of a few miles natural processes in the river frequently reduce the fæcal organisms to a small fraction of the number discharged. Such an effluent cannot be treated with chlorine to destroy bacteria without first considering the possible effects on the life of aquatic organisms. With some effluents, for example, a dose of chlorine much smaller than the chlorine demand is sufficient to make the liquid highly toxic to fish.

Three examples of trade wastes were chosen to illustrate different types of microbiological problems.

Effluents from dairy premises are particularly liable to cause blocking of percolating filters, the high proportion of carbohydrate resulting in excessive growth of biological film. Investigation has shown that if this film, which consists largely of a tough mat of fungal mycelium, be subjected to starvation, the protoplasm becomes concentrated in certain cells of the mycelium, leaving others empty, thus weaken. ing the mechanical strength of the fungal mat, which quickly disintegrates. In practice, this period of starvation is ensured by employing two filters in series, the effluent from the first filter being fed to the second filter. At suitable intervals the order of the filters is reversed. By this process-now known as alternating double filtration-it is possible to treat certain liquids at three or four times the normal rate.

Disposal of highly polluting waste liquors from the retting of flax has been avoided by subjecting the liquid to continuous aeration during the process of retting. Bacterial oxidation prevents the liquor from becoming acidic and foul-smelling, and reduces the content of organic matter, so that the liquid can be re-used for successive batches of flax.

In the manufacture of beet sugar, the practice of re-circulating the waste waters to diffusers in order to avoid discharging them leads to corrosion in the re-circulation system. Investigation has shown that this is due to formation of acid by thermophilic lactobacilli which can be prevented from growing by applying chlorine to the contents of the battery supply tank or by maintaining the re-circulation system at a sufficiently high temperature.

Mr. T. G. Tomlinson described the percolating filter as an artificial habitat in which both terrestrial and aquatic organisms are found in far greater abundance than in their natural surroundings. The types of fungi which predominate there are largely determined by the character of the liquid being treated. Saprolegnium, for example, is encouraged by domestic sewage and by waste waters from processing of food but is inhibited by the trade wastes from large towns; in filters treating the latter, it is usual to find instead two species of Sepedonium, characterized by tuberculate chlamydospores, accompanied by Ascoidea mubescens, which often produces large ovoid conidia. Fusarium aqueductum occupies a rather special place in the surface flora of percolating filters because its holdfast, prostate system of filaments enables it to cling firmly to the medium when washed by the jets of liquid from the distributor.

The population of protozoa shows a gradation throughout the depth of the filter. Polysaprobic zones at the surface contain Opercularia, Paramecium caudatum, Colpidium, and Glaucoma. In the mesosaprobic zones lower down are Aspidisca costata, Euplotes, and testaceous rhizopods; rotifers are found towards the bottom.

Of the Oligochæta, Lumbricillus lineatus, a small red worm possessing hæmoglobin, occurs universally in percolating filters throughout the whole year. The handicap of a long generation time and low fecundity is compensated by a low metabolic rate and a strongly gregarious habit.

Among the more numerous insects are two species of Psychoda, two of Spaniotoma, two of Metriocnemus, Anisopus fenestralis, Anisopus collembola, Achorutes subviaticus, and Tomocerus minor. The controlling factor in the balance of these species is the amount of film, which in turn depends on the rate at which sewage is applied to the filter. During the warmer months Psychoda alternata, with a life-cycle of four weeks at $15^{\circ} \mathrm{C}$., and of two weeks at $21^{\circ} \mathrm{C}$, , is dominant. Anisopus fenestralis develops more slowly than Psychoda, requiring three months for completion of its life-cycle at $10^{\circ} \mathrm{C}$., but its larvæ remain 
active at temperatures below $10^{\circ} \mathrm{C}$, so that eggs laid in late autumn may give rise to a generation which matures slowly throughout the winter and emerges in the spring.

Dr. Ll. Lloyd, describing the part played by insects and worms in the disintegration of the biological film in a percolating filter, said that whereas in winter surface growth is usually much in evidence and the medium is slimy throughout the depth of the filter, in summer the same medium often appears perfectly clean. In general, depletion in the quantity of biological film has no effect on the efficiency of the filter.

The effect of film depletion is reflected in the behaviour of the flies, and a very good example is afforded by the study of species of Psychoda at Leeds. Here the number of $P s$. severini reaches a peak in May but is small at any other time of the year. Ps. alternata shows a peak in June which is followed by a steady decline, and the sequence is then taken up by Spaniotoma minima, which builds up an enormous population in the autumn. If the supply of food is sufficient, all three species will breed abundantly from spring to autumn; curtailment of the food supply tends to restrict development, the species which predominates depending on factors which give it a seasonal advantage over its competitors. Introduction of midges (Metriocnemus species) introduces a complicating factor. Although essentially grazers on film, they take readily to a predatory habit and when present they tend to restrict the numbers of the three species of flies just mentioned.

There is also some evidence that food supply affects the size of flies. In the absence of other factors, size depends on temperature, wing-length increasing by about 2 per cent for each fall of $1^{\circ} \mathrm{C}$. in later larval life. In fact, however, the steady increase due to this factor in the size of flies emerging from August onwards shows periodic interruptions which suggest the effect of shortage of food.

Mr. F. T. K. Pentelow said that the effects of pollution on fisheries may result from damage either to the fish themselves, to their spawn or spawning ground, or to their food. Conclusions from toxicity experiments are complicated by the fact that toxicity is greatly affected by the concentration of such sub. stances as calcium in the diluting water, by the concentration of dissolved oxygen, and by the temperature. An idea of the toxicity of different substances is given by the following figures, which express, in parts per million, the concentrations found to be toxic to trout under average conditions : cyanide, 0.15 ; sulphide, $1 \cdot 0$; chlorine, 0.2 ; phenol, 9.0 ; sulphuric acid, 10.0 ; para-cresol, 6.0 ; 1.2 .6 xylenol, 10.0 ; the toxicity, to sticklebacks, of copper is about 0.02 and of zine about 0.3 .

The mode of action of poisons varies widely. Cyanide, for example, destroys the enzyme responsible for transferring oxygen from the blood to the tissues, phenols and cresols appear to be nerve poisons, and heavy metals prevent respiration by coagulating the mucus over the body and gills. With some poisons the toxic action is reversible, affected fish recovering after transference to fresh water, but with other substances it is not. Thus, a shoal of fish subjected to the action of phenol from a temporary discharge of gas liquor might easily recover if the current carried them to a zone of cleaner water, but fish affected by discharge of chlorine or ammonia in similar circumstances would die. The behaviour of fish towards a particular substance is no criterion of its toxicity. They will, for example, keep strictly away from waters containing the less toxic zinc salts, but are so indifferent to the presence of the highly toxic copper salts that they are rapidly killed.

Bacterial oxidation of discharged organic matter results in depletion of oxygen in the river water. Though fish may not be actually asphyxiated until the oxygen content falls to between $0 \cdot 1$ and 0.2 part per 100,000, in practice it is frequently found that fish are absent from waters in which pollution has reduced the value to about 0.5 part per 100,000 .

The effect of pollution on spawn and spawning grounds is almost unknown territory, but more is known about its effect on fish food. In general, pollution of streams by organic matter frequently results in replacement of the characteristic flora and fauna by other types, but without necessarily reducing the total quantity of material acceptable to fish as food. Pollution by inorganic substances is a very different matter. For example, discharge of copper wastes to a stream has been known to render it unable to support the life of trout, even in zones downstream where the concentration of copper is much too small to be directly toxic ; this is because the copper has destroyed the animal life on which carnivorous fish like trout depend.

\section{THE ROYAL ACADEMY, 1948}

\section{BY DR. A. TINDELL HOPWOOD British Museum (Natural History)}

COCRATES once likened books to pictures because, "the creatures of the latter art stand before you as if they were alive, but if you ask them a question, they look very solemn and say not a word". To an argumentative old man the lack of response was deplorable; but to the pictures themselves, had they been sentient, it would assuredly have been the height of wisdom. Many a canvas would be covered with confusion, and mantled with blushes, were it suddenly to be faced by Socrates and to hear the dread question, "Why were you painted ?" Imagine the unease of the self-confessed pot-boiler, the tearful admission of the failures, and the venomous hatred of the shams. No, it is just as well that pictures cannot reply in words. On the other hand, our questions are not left entirely unanswered; but some degree of skill is needed to decipher the very solemn faces masking the replies.

Now, morally there is nothing wrong with an honest pot-boiler. A certain snobbish section of the public is only too ready to repeat hollow phrases about 'art for art's sake', without pausing to reflect that artists, like other men, must eat. Provided that the painter of a pot-boiler has the pride proper to a good craftsman, he plays a useful part in life, even though he does not produce a masterpiece. After all, and we may just as well admit it, none of the great masters of the past, not even Rembrandt or Turner, was consistently inspired; many a picture to which a famous name is attached is to be valued for its craftsmanship rather than for its genius. So let us praise honest craftsmanship wherever we find it, rather than indulge in unkind sneers at the unfortunate whose inspiration has forsaken him for a while. 